SUSTAINABLE FORESTRY

COLLECTION 75-76, 2017
ODRŽIVO ŠUMARSTVO

ZBORNIK RADOVA 75-76, 2017

UDK $630 * 416.11(497.11)=111$

Original scientific paper

\title{
STUDIES OF DEFOLIATION ON ICP SAMPLE PLOTS LEVEL I IN REPUBLIC OF SERBIA
}

\author{
Tomislav STEFANOVIĆ ${ }^{1}$, Renata GAGIĆ-SERDAR ${ }^{1}$, Ilija ĐORĐEVIĆ ${ }^{1}$, \\ Goran ČEŠLJAR ${ }^{1}$, Natalija MOMIROVIĆ ${ }^{1}$, Ivana ŽIVANOVIĆ ${ }^{1}$, \\ Radovan NEVENIĆ ${ }^{1}$
}

\begin{abstract}
Project of forests condition monitoring (ICP Forests) operates as an international European project in which, on grid of ICP sample plots (bioindication points) condition of forests has been monitored annually in continuity, including recording data on defoliation with evidencing any damage to the trees. The main goal of the program is monitoring of condition of forests on a permanent, representative surfaces, arranged in a systematic grid distributed on the territory of of Europe. This paper analyzes the data on defoliation as part of the results of the forest conditions monitoring on ICP sample plots on the territory of the Republic of Serbia, in the period 2012 - 2016. The assessment of defoliation is performed on the experimental fields regardless of the cause of loss of leaves, because the results are not aimed to determinate the cause-and-effect relationships, but only to represent the state of defoliation on this study sample plots in the researched period. Assessment and analysis of the degree of crown defoliation has been presented for most common tree species as the most noticeable crown health indicators. Linking these results with other indicators of environmental conditions will provide more concrete informations, and draw conclusions about the vitality of the plants depending on ambient conditions.
\end{abstract}

Key words: Defoliation, ICP sample plots, crown condition monitoring, Serbia

\section{STUDIJE DEFOLIJACIJE NA BIOINDIKACIJSKIM TAČKAMA (ICP FORESTS) NIVOA I U REPUBLICI SRBIJI}

\footnotetext{
${ }^{1}$ Institute of Forestry, Kneza Viseslava 3, Belgrade, Serbia
} 
Izvod: Projekat monitoringa šuma (ICP forests) odvija se kao međunarodni evropski projekat u kojem se na mreži oglednih površina (bioindikacijske tačke) stanje šuma prati na godišnjem nivou u kontinuitetu, uključujući evidentiranje podataka o defoliaciji i evidentira se oštećenja drveća. Osnovni cilj programa je praćenje stanja šuma na trajnim, reprezentativnim površinama, raspoređenih u sistematsku mrežu distribuiranu na teritoriji Evrope. Ovaj rad analizira podatke o defoliaciji kao deo rezultata monitoringa stanja šuma na biondikacijskim tačkama na teritoriji Republike Srbije, u periodu od 2012. do 2016. godine. Procena defoliacije se vrši na eksperimentalnim poljima, bez obzira na uzrok gubitka listova, jer rezultati nisu usmereni na određivanje odnosa uzroka i efekta, već samo da predstavljaju stanje defoliacije na ovim istraživačkim uzorcima u istraživanom periodu. Procene i analize stepena defoliacije kruna, predstavljene su za najčešće vrste drveća kao najznačajniji pokazatelj njihovog zdravstvenog stanja. Povezivanje ovih rezultata sa drugim indikatorima uslova sredine obezbediće konkretnije informacije i doneti zaključke o vitalnosti biljaka u zavisnosti od uslova okoline.

Ključne reči: Defoliation, ICP sample plots, crown condition monitoring, Serbia

\section{INTRODUCTION}

In Europe, the issue of forest decline emerged as the major environmental concern of the 1980s (Innes, 1993a). As a consequence, the 'International Cooperative Programme on Assessment and Monitoring of Air Pollution Effects on Forests' (ICP Forests) was established in 1985 by the Economic Commission for Europe of the United Nations under the Convention on Long-Range Transboundary Air Pollution (Innes et al. 1993). Within the framework of the ICP Forests Programme, efforts were made to widely harmonise and standardise methods for forest monitoring throughout Europe. The methods were recorded in the ICP Forests manual (UNECE, 2010) that was first published in 1985 and has continuously been subject to updates since its publication.

The forest condition survey represents an essential part of the forest monitoring, which was described in Part IV of the ICP Forests manual (Eichhorn et al. 2010) and became mandatory throughout the European Union in 1987 (Redfern and Boswell 2004; Solberg and Strand 1999). The survey on forest condition has been conducted annually on the systematic wide-scale monitoring plots (Level I), which were established wherever forest coincided with a $16 \times 16 \mathrm{~km}$ grid over Europe, as well as on plots of the intensive monitoring programme (Level II; since the 1990s) (Eichhorn et al. 2010; Ferretti et al. 1999; Innes 1993b).

Paper analyzes the data of defoliation as part of the complete gethered results of the monitoring of forest on all ICP Forests extensive sample plots, after their network revision in the Republic of Serbia. Serbian language abbreviation usually and commonly used is BIT as Bio Indicational Plot (Bio Indikacijska Tačka). Monitoring of forests is carried out continuously at 118 experimental fields. Field work on data collection (observations and measurements), in the previous period were carried out in the period June - September each year. Calculations of the defoliation mean values for each sample plot and for the most common tree species, allowed the comparison of the values of defoliation in some regions and by tree species. Despite much criticisms (Innes et al, 1993) defoliation, a visual estimate of the lack of foliage on a tree, becomes soon the key response 
variable assessed in forest health surveys in Europe, and it is now firmly established in the European reporting system (FOREST EUROPE et al. 2011). Defoliation is estimated with respect to a reference standard and according to $5 \%$ of classes, from 0 (no defoliation) to 100 (dead tree) (Eichhorn et al. 2010). It is unspecific, as lack of foliage may be caused by several agents, and is considered as an overall proxy indicator for forest condition (Travaglini, 2013). The importance of defoliation assessment is based on the assumption that stress factors and damage agents usually cause a reduction in foliar mass, and defoliated trees have a reduced chance of survival as they are more vulnerable to attacks by pathogens (TabakovićTošić, \& Marković 2004; Mihajlović, 2008; Karadžić 2010). Defoliation is assessed on an annual basis in almost all the countries participating in the ICP Forests (e.g. Seidling and Mues 2005), and data are summarized in international reports (ICP Forests and FUTMON 2011).

This has been realised by long-term, comprehensive and intensive forest condition monitoring for already 20 years within the ICP programme for forests and by the Convention on Long Range Transboundary Air Pollution of the European Union. The European Commission also compiled the Report on the results for all EU member states. The first collective Report by EU/ICP Forests on forest condition in Europe was published in 1992. After 12 separate Reports, the European Commission decided in 2004 that the Report on forest condition should be published as one Report named ICP Forests Report. The European Commission Regulation No. 1091/1994 laid down the legal base for the Level II programme. Step by step, 860 permanent observation plots for Level II intensive forest condition monitoring have been established in 28 countries. The main protagonists of ICP Forests are the nine Expert Panels and Working Groups whose researchers from the participating countries take part in the programme, develop and amend the applied methods. They are also responsible for the steering and the supervision of the projects and for the project integration. The wide collaboration of the European countries and the engagement of their experts guarantee the success of this programme, which will be even more significant in future (FOREST EUROPE, UNECE and FAO, 2011).

Every year, the Republic of Serbia by its National Focal Center for Forest Condition Monitoring participates actively in the ICP Forests programme, publishes the results, and submits large-scale reports to the Directorate of Forests and ICP Forests in Hamburg. This paper presents the work of the researchers from 2009 to 2012 who gave their contributions to the obtaining of the results of forest condition monitoring at the local and international levels within their respective institutions.

The Ministry of Agriculture, Forestry and Water Management of the Republic of Serbia - Directorate of Forests assigned the tasks of coordination and management of the programme ICP Forests to the Institute of Forestry - National Focal Centre of the Republic of Serbia. The aim of the author of the text in this paper is to present the total survey - comparative analysis and results of the four years research, forest condition monitoring in the Republic of Serbia.

In this article, we focus on tree condition as measured by the degree of defoliation (needle loss), affecting the tree on sample plots in Serbia. We surveyed the regional distribution of tree health, with an extensive monitoring network, 
during four year's period (2012 - 2016) in Serbia, with the aim to answer the following questions:

(1) How large is the annual variation in defoliation between plots and within plots over years (i.e., plotxyear interaction)?

(2) What is the relative contribution of tree species to the variation in tree defoliation levels?

(3) How useful/sensitive are extensive tree health monitoring networks to reveal the impacts of widespread leaf/needle loss?

Country Serbia has its unique country code, number 67, based on the disposition of the countries participating in ICP programme. In 2003, after the study of the procedure of forest condition monitoring based on ICP methodology (Ferretti \& Chiarucci, 2003), the training course was organised at the Institute of Forestry, for the experts selected to perform the crown condition assessment. In collaboration with the Institute of Lowland Forestry and Environment, 103 sample plots in $16 \times 16 \mathrm{~km}$ grid were reconstructed and the crown condition of forest trees was assessed. On the area of Serbia (without Kosovo and Metohija) it was necessary to revise the old plots according to the Level I cooperative programme (Stefanović et al, 2003), as well as the control and harmonisation with the installed coordinate network at the level of Europe. NFC of Serbia also carried out the entry and application of the reconstructed sample plots in the GIS (Geographic Information System) Database (Nevenic, 2008). In 2004, it was concluded that the reconstructed 103 sample plots did not represent fully the status of vegetation cover in Serbia, so that additional 20 sample plots were selected and installed on the area of central of Serbia, and 7 new plots in Vojvodina. The total number of installed sample plots in the Republic of Serbia was then 130 sample plots. The Institute of Forestry, in collaboration with the Faculty of Forestry and the Institute of Lowland Forestry and Environment, carries out the monitoring and assessment of the forest health status on the territory of Serbia. In 2004, the more in-depth monitoring of forest tree diseases and soil chemistry on additional 20 sample plots was realised by the Faculty of Forestry in Belgrade. The analysis of 106 samples of forest nutrition were analysed in the laboratories of the Institute of Forestry (43 samples) and the Faculty of Forestry (63 samples). The GIS database in NFC of Serbia was updated for the additional 20 new plots (Nevenic, 2009).

In 2012, the activities on forest condition monitoring were continued in Serbia on 130 sample plots (Figure 1.)

The most represented species at "BIT" are Fagus moesiaca L., Quercus cerris L., Quercus frainetto Ten., Quercus petraea (Mattuschka) Liebl. and Carpinus betulus L. The represented coniferous tree species are Abies alba Mill., Picea abies(L.) H. Karst., Pinus nigra J.F.Arnold and Pinus silvestris L.

\section{1. Objects of research}

The complex of anthropogenic and natural stresses and especially air pollution continues to be regarded as an important stress factor in nature. The significance of atmospheric pollution varies, its impact depends on the region, and its effects on the site and stand conditions. Air pollution and its effects on forest ecosystems are complex and difficult to isolate and quantify. Forest condition is also influenced by 
a large number of other stress factors which must therefore be taken into consideration. The ICP Forests mandate, therefore, is monitoring of the effects of anthropogenic factors (in particular air pollution) and natural factors on the condition and development of forest ecosystems in Europe. Also it is contribution to a better understanding of cause-effect relationships in forest ecosystem functioning in various parts of Europe. Based on its mandate, ICP Forests pursues the following objectives:

- to provide a periodic overview on the spatial and temporal variation in forest condition in relation to anthropogenic, in particular air pollution, as well as natural stress factors, on the systematic network of sample plots of Level I (Ferretti et al, 1999);

to contribute, in co-operation with the ICP on Modelling and Mapping, to the calculation of critical levels/loads and their exceedances in forests and to improve collaboration with other environmental monitoring programmes inside and outside the CLRTP (Convention on Long-Range Transboundary Air Pollution)

- to a better understanding of the relationships between the condition of forest ecosystems and natural stress factors, in particular air pollution (Ferretti et al, 2010a)

Intensive monitoring has been conducted on a selected permanent sample plots spread over Europe (Level II). Permanent observations of numerous parameters on these sample fields are performed in the aim of

- monitoring the status of the most important (common and representative) forest ecosystems in Europe;

- to provide a deeper insight into the interactions between the various components of forest ecosystems by compiling available information from related studies.

In the realisation of the objectives, the continued forest condition monitoring in the European countries, ICP Forests consists of the following three levels of monitoring intensity. Level I includes forest condition monitoring on sample plots in 16 x $16 \mathrm{~km}$ grid - monitoring, Observation and analyses: crown condition assessment, status of forest nutrition, research and information on soil condition, forest tree diseases, etc. The data on forest condition obtained at this level cover the widest area of Europe. Level II includes the intensive monitoring on a number of permanent observation plots. Monitoring and research at this level are more detailed and they deal with a greater number of input parameters. The Level II results lack the large-scale representativeness. The concept of the higher level of forest condition monitoring intensity enables the correlation of the obtained results with the Level I results, by the comparison of Level II data and the extrapolation to a large scale (Nevenić et al. 2013). The extrapolation of Level II data is aimed at:

- Evaluation of the significance of relationships at the European level (Ferretti et al, 2010b)

- Limiting of the geographic area (within Europe) for which the relationships are true. The precondition for extrapolation is the harmonised level of monitoring. Level III is the highest level in the hierarchy of monitoring intensities. It includes in-depth analyses of interactions in forest ecosystems, starting from the published 
scientific results and the results of monitoring obtained by the activities which exceed the Level II (UNECE, 2010b).

In 2002, the activities of some researchers at the Institute of Forestry were directed to the International collaboration and the participation of our country in the EU programmes. After several years, the collaboration with ICP Forests, PCC Head office in Hamburg, was re-established. The Forest Directorate established and verified the Institute of Forestry as the National Focal Centre (NFC) of Serbia for monitoring forest condition.

\section{METHODS AND CRITERIA}

Reserach had been done according to the ICP Forests Methodology. In 2012, the activities on forest condition monitoring were continued in Serbia on 130 sample plots (Figure 1.) A sample plot is spatially determined by a co-ordinate grid of sample plots and entered into the GIS database (Figure 2.) It is marked with a brightly coloured metal stake driven in the centre. The sample trees for crown condition assessment are selected systematically as 4-point cluster. Oriented along the main compass directions at a distance of $25 \mathrm{~m}$ from the grid point - stake, the 6 trees (24 sample trees per plot) nearest to the subplot centre are selected as sample trees. The tree sample includes all tree species, provided the trees have a minimum height of $60 \mathrm{~cm}$. The trees selected for assessment are classified according to crown canopy classes after Kraft (dominant, codominant, subdominant, suppressed, dying), but they must be without significant mechanical damage. The selected trees are permanently marked by numbers for future permanent assessment. The trees removed by management operations or for other reasons, are replaced by the new selected trees. If the stand is removed by clear felling, the grid point should be kept till the establishment of the new stand. Within the national and transnational survey (Level I) crown condition is expressed by the classes of defoliation, discolouration and combined damage classes (Seidling \& Mues, 2005). Defoliation is assessed in 5\% steps and it is grouped in 5 classes of unequal extent (Table 1).

\section{RESULTS}

During this period, the defoliation of Norway spruce and black pine has remained quite constant, while the defoliation of Scots pine slightly increased during the final years of the reporting period, e.g. in 2016 (Tab 3). The annual mean defoliation in coniferous values were as follows: Scots pine, increased from 8 ,9in 2012 , to $11,6 \%$ in 2013 , Norway spruce increased from $6,0 \%$ in 2013 , to $8,0 \%$ in 2014 and Fir signnificantly increased from $4,0 \%$ in 2013 to $15,6 \%$ in 2016 (Češljar et al. 2013).

Of all the trees assessed, $89,6 \%$ of the coniferous, and aprocsimatelly the same persentage of the broadleaves were not defoliated. Only moderate defoliated (leaf or needle loss was more than $25 \%$ ) in whole period were sample trees of black pine. In 2012, the proportions without defoliation were $\approx 91 \%$ in Scots pine, $\approx 94 \%$ in spruce and $95.5 \%$ in fir, respectively (Table 2 and 3). The proportion of 
moderate defoliated trees (defoliation more than 25\%) has remained relatively constant, and for black pine these figures were $29.5 \%$ in 2013, the highest, than with $28,4 \%$ in 2014, 28.4\% in 2014 and similar 27,5\% in 2015 and 2016, respectively. Looking at the observed period, it can be concluded that the data for defoliation with conifers and deciduous trees were at a fairly balanced. With coniferous and deciduous trees condition in 2012 set aside as the most unfavorable, as manifested by fewer defoliation on unaffected trees. In conifers, the situation was slightly better in 2013 and 2014 (Češljar et al 2013):, while for the deciduous 2015 year was similar to the 2016. As defoliation is concerned, the only real legitimacy is evident in the strong defoliation of conifers, however, and it is difficult to talk about the trend because of the very small number of trees affected by this category of damage (total number is 10 trees). In observed period F.moesiaca was the most resistant species; on the many sample plots no signs of the defoliation were detected, whereas the weak defoliation of the trees was identified. Oaks are the most suspectible to the foliage loss, most notably sessile oak, with the two-thirds trees with the moderate and weak defoliation. The situation in observed period was the similar with the condition from the previous years, regarding $Q$. cerris and $Q$. fraineto. The Slight defoliation of the coniferous trees was present on the spruce trees; a great number of trees were without the visible signs of this process. Fir is more vulnerable in regard to decissation. Twothirds of the observed trees of this species were not subject to the defoliation at all, whereas the loss of the needles of the weak and moderate intensitivity were identified on the other trees (Figure 5). The presence of the damage on the observed broadleaf trees is connected with the assessment of discolouration and defoliation. The parametres of this category and their values are close, i.e. they are approximately in the middle between the above discussed percentages of these two processes. The phenology of the observed species, i.e. leaf rejection in the autumn, make the broadleaves superior from this aspect. In 2012 beech was the most resistant species, these trees on the all sample plots were without no damage. Spruce is most vital conifer species, without any damage. It is followed by fir with $85.5 \%$ of trees without defoliation. During the 2012 droughts that caused the drying sessile oak forests in the mountain regions assumed the serious proportions; more and approximately $20 \%$ of affected trees. As the main reason for the drying indicated a significant decrease in soil moisture content due to increase in temperature and decrease in rainfall. The incidence of increased temperature during vegetation period and frequent dry vegetation periods were the cause of weakening these forests. Conditions formed by these micro climate changes were the main movers and intensive local factors for gradation of plant pests (pest moths and damaging epidemics of oak powdery mildew) - just about the phenomenon of indirect impacts of climate change on forest extinction (Chiru \& Chira 1998; Halmschlager 1998).

Country about affected trees with defoliation for the period $2012-2016$ are shown in Tables 2 and 3, and for more realistic impression are showen on Figures 3-7. These maps enable more plastic presentation of spatial variance of defoliation value.

Despite the relatively small changes in defoliation in the whole data, marked spatial and temporal variations in defoliation existed during the study period. The 
defoliation in 2012 and 2013 was highest in northern Serbia (Fig.3 and 4): Results of research of defoliation on bio-indicator plots in Republic of Serbia in 2013(Stevanovic et al 2013). The highest defoliation values in 2014 were found in norhtern and at south (Fig.5). The defoliation of all sample trees in 2014 was simmilar to 2015, with some surfaces highest in northern Serbia (Fig. 5) and scattered across the country (Fig. 6). The highest values were found in the easternmost parts of Serbia in observed period. The defoliation of the assessed trees seems to have intensified in 2016 in the nortmost parts of the country, as compared to a more diffuse pattern previously (Fig. 7).

\section{DISCUSSION}

Forests with their sustainable management today present one of the many principal international and national policies issues. To be really sustainable, forest management requires the information on the factors that affect the forest health per vitality, biodiversity and ecosystem functioning status. To date, numerous studies have assessed the impact and the importance of shaping of defoliation has received renewed scientific attention, on ICP extensive level (Ferretti et al, 1999; Nevalainen et al, 2010). Tree species-specific effects are regulated by mechanisms allowing for resistance to disfoliating. The short-term consequences of leaf or needle loss depend on species abilities to resist to many factors, and to recover after, and on competitive interactions between species. Although the abundance of many species generally decreases during process so some taxa may increase in number during observed period or shortly after. The effects of recurrent accurence asimilation organs rejection must be evaluated in the wider context of global climate and habitat change (Nevenić et al, 2011). Considering the predicted increase in defoliation frequency and intensity (UNECE, 2004), interdisciplinary research initiatives on this issue are needed urgently. Our results suggest that extensive monitoring networks can reveal useful information about the widespread outbreaks of pest organisms (insects and fungi) already in their increase phases, giving some time for management decisions (Edgar \& Burk, 2006). In a changing climate, large-scale, regular monitoring of tree health, including abiotic and biotic causes, is more important than ever before.

\section{CONCLUSIONS}

Defoliation frequency is thought to be the main driver of vegetation dynamics in Serbia and its temperate forests according ICP extensive sampling. The decline of oak forests has been linked to the detrimental effects of recurrent droughts.

Although five years is relatively short period of meticulously statistical processing in terms of comparative analysis, by examining the collected data values for defoliation and discolouration, some conclusions could yet be to come. Certainly, primarily because of the short time period analyzed, any conclusions reached should be accepted with reservations, or conditionally interpreted as a trend. Oscillations of annual values for three element processed reprezent state of 
health of forests (defoliation, in all categories of vulnerability, for the conifers are more pronounced than in deciduous trees case). Project of forests condition monitoring - ICP Forests Programme, operates as international European project which demand performing annually observation of forests with recording data on defoliation, discoloration and other damage recorded on the trees, distributed in network of sample plots with special purpose called bio-indicator points or BIT.

Paper analyzes the data of defoliation as part of the complete gathered results of the monitoring of forest on all "BIT", after their network revision in the Republic of Serbia. Monitoring of forests is carried out continuously at 130 mentioned sample plots. Field work on data collection (observations and measurements), in the previous period were carried out in the period June September each year.

Calculations of the defoliation mean values in period $2012-2016$, for each sample plot and for the most common tree species, allowed the comparison of the values of defoliation in some regions and by tree species.

In deciduous forests beech and hornbeam are proven to be more resistant species, in a process of defoliation than oaks. Sessile oak was the most endangered species among the broadleaved. Among the coniferous trees, spruce proved to be a resilient species, while the black pine trees were far the most vulnerable to these processes of all registered species on sample plots.

Determination of defoliation mean values for each experimental field area has allowed mapping of defoliation. Such maps have allowed more plastic and much clearer image of spatial variations of defoliation change (Nevenić et al, 2015).

At the sample plots assessment of defoliation were done even regardless the leaves/needles loss cause, and the results are not strictly aimed to determinate the cause-effect relationship. They are only representing the state of defoliation on experimental fields for the processed period in this paper. Still, the presented study is a baseline for monitoring of changes in forest conditions and connectivity of these results with other indicators of environmental parameters will provide more specific information, and making conclusions about the vitality of plants dependence on environmental conditions.

Leaf or needle loss is certainly a widely underestimated ecological stress and selection force fully exerted to forest ecosystems in Serbia. Our observations have revealed a number of issues that should have priority in future research, such as:

1. Environmental factors. Variations of factors such as defoliation intensity, duration and return frequency, species-specific phenotypic plasticity, adaptive potential and phylogenetic and physiological constraints must be experimentally identified in relation to environmental events. This should lead to a concise classification of species according to their sensitivity to asimilation organs rejection with exactly environmental features linked to. Particular focus must be on vulnerable species and ecosystems, because these will probably be the first to be seriously affected by appereance of recognised defoliating in progress.

2. The continuity. Long-term monitoring programs should be continued or developed, since these are the only way for evaluating the impact of defoliation as events on ecosystems. However, these programs should be coupled with integrative 
experimental and modelling approaches to enhance our understanding of complex leaf drought and loss effects.

3. Idioeclogical dimension. The impact of defoliation on ecosystem processes must be studied to better understand how it alters ecological functions and how these effects are influenced by species composition. All should help to define an indicator system for predicting drought sensitivity at the stand and forest levels.

3. Clarifying the causal and consequential relationship. Future research should focus on the simultaneous effects of different factors as causers, such as pests, forest management, pollution and global warming. This is essential for identifying the most relevant factors that mediate the impact of defoliation as events on forest biodiversity.

4. Prevention of gain losses in the wood production. The impact of strategies that are being proposed to mitigate the effects of leaf or needle loss on trees on forest biodiversity should be rapidly evaluated, especially where the impact of the accurence leads to yield reduction.

4. Biodiversity. The effects of defoliation events on forest biodiversity should be considered in both planning (e.g. tree species selection) and management (e.g. retention of deadwood).

\section{LITERATURE}

Chira D \& Chira F (1998) Beech problem in Romania, In: Proceedings of a workshop of IUFRO working party 07. 02. 06., Disease / environment interaction in forest decline. 2329. Vienna

Češljar G., Nevenić R., Bilibajkić S., Stefanović T., Serdar G.R., Đorđević I., Poduška Z. (2013): Vitalnost stabala na bioindikacijskim tačkama nivo-a 1 u Republici Srbiji u 2013. godini. Sustainable forestry, Collection tom 67-68: 69-78.

Češljar G., Gagić Serdar R., Đorđević I., Poduška Z., Stefanović T., Bilibajkić S., Nevenić R. (2014): Analysis of types of damages at the sample plots of level 1 in 2013 at the territory of the Republic of Serbia, Sustainable forestry, Collection tom 69-70: 63-71.

Edgar C B \& Burk T E (2006). A simulation study to assess the sensitivity of a forest health monitoring network to outbreaks of defoliating insects. Environmental Monitoring and Assessment, 122, 289-307.

Eichhorn J, Roskams P, Ferretti M, Mues V, Szepesi A \& Durrant D (2010) Visual assessment of crown condition and damaging agents. In UNECE (Ed.), Manual on methods and criteria for harmonized sampling, assessment, monitoring and analysis of the effects of air pollution on forests (pp. 49). Hamburg, Germany: UNECE, ICP Forests Programme Coordinating Centre.

Elzinga C, Salzer D W, Willoughby J W \& Gibbs J P (2001) Monitoring plant and animal populations. MaIden: Blackwell Science, Inc.

Ferretti M (1997) Forest health assessment and monitoring - Issues for consideration. Environmental Monitoring and Assessment, 48, 45-72.

Ferretti M (1998). Potential and limitation of visual indices of tree condition. Chemosphere, 36(4-5), 1031-1036. 
Ferretti M, Bussotti F, Cenni E, \& Cozzi A (1999) Implementation of quality assurance procedures in the Italian programs of forest condition monitoring. Water, Air, and Soil Pollution, 116, 371-376.

Ferretti M (2004) Forest health diagnosis, monitoring and evaluation. In J. Burley, J. Evans, \& J. Youngquist (Eds.), Encyclopedia of forest sciences (pp. 285-299). London: Elsevier Science.

Ferretti M \& Chiarucci A (2003) Design concepts adopted in long-term forest monitoring programs in Europe problems for the future? Science of the Total Environment, 310, 171178.

Ferretti M, Fischer R, Mues V, Granke O, \& Lorenz M (2010a). Basic design principles for the ICP ForestsMonitoring Networks. Manual Part II, 22 pp. In Manual on methods and criteria for harmonized sampling assessment, monitoring and analysis of the effects of air pollution on forests. UNECEICP Forests Programme Co-ordinating Centre, Hamburg. http://www.icp-forests.org/Manual.htm. Accessed 2 May 2014.

Ferretti M, König N \& Granke O (2010b). Quality assurance within the ICP Forests monitoring programme. Manual Part III, $11 \mathrm{pp}$. In Manual on methods and criteria for harmonized sampling, assessment, monitoring and analysis of the effects of air pollution on forests. UNECE ICP Forests Programme Co-ordinating Centre, Hamburg. http://www. icpforests.org/Manual.htm. Accessed 20 May 2014.

FOREST EUROPE, UNECE and FAO (2011). State of Europe's forests 2011. Status and trends in sustainable forest management in Europe. Ministerial Conference on the Protection of Forests in Europe, FOREST EUROPE Liaison Unit Oslo, pp 336.

Innes J L (1993) Forest health: its assessment and status, Wallingford: Can International.

Innes J L, Landmann G \& Mettendorf B (1993) Consistency of observations of forest tree defoliation in three European countries. Environmental Monitoring and Assessment, 25, 29-40.

Halmschlager E (1998): The possible role of Armillaria spp. and Phytophthora spp. in the oak decline complex. Iz: Proceedings of a workshop of IUFRO working party 7. 02.

06, Disease / environment interaction in forest decline. 49-56. Vienna.

Nevalainen S, Lindgren M, Pouttu A, Heinonen J, Hongisto M, Neuvonen S (2010) Extensive tree health monitoring networks are useful in revealing the impacts of widespread biotic damage in boreal forests, Environmental Monitoring and Assessment, Volume 168, Issue

Nevenic, R and a group of authors (2008) Праћење стања шума у Републици Србији према програму ICP за шуме (International Cooperation Programme for Forest Monitoring ) и конвенцији CLRTAP (Convention on Long Range Transboundary Air Pollution)Annual Report ICP Forests 2008 Level I. Institute of Forestry, Belgrade. pp 15 ISSN: $1452-8576$

Nevenic R (2008) GIS as a Tool in Forest monitoring in Serbia in a frame of ICP Forest Monitoring Programme. Symposium of Computer and Informatical Technologies YU INFO 2008. Kopaonik, Serbia. Proceedings, pp. 284-287. ISBN 978-85525-03-02.

Nevenić R, Tabaković-Tošić M, Rakonkac Lj (2009) Neki pokazatelji vitalnosti šuma Republike Srbije, Monografija, Institut za šumarstvo, Beograd. 
Nevenić R, Rakonjac Lj \& Orlović S (2011) Praćenje i procena uticaja zagađenja vazduha i njegovih efekata u šumskim ekosistemima na teritoriji Republike Srbije - monitoring stanja šuma, Nivo I i Nivo II, Monografija, Institut za šumarstvo, Beograd.

Nevenić R., Bilibajkić S., Poduška Z.,Češljar G., Stefanović T., Đorđević I., Serdar R. G. (2013)Stanje kruna stabala na oglednim poljima BIT nivo-a II Kopaonik, Crni vrh i Mokra gora u 2013.godini. Sustainable forestry, Collection tom 67-68:79-94.

Nevenić, R., Tabaković-Tošić, M., Rajković, S., Rakonjac, Lj., Miletić, Z., Bilibajkić, S., Marković, M.,

Stefanović, T., Jović, Đ., Radulović, Z., Milanović, S., Stajić, S., Čokeša, V.,., Gagić Serdar R., Đorđević, I., Češljar, G., Drekić, M., Jovanović, V., Pivić, R., Brebanović, B., Galić. Z., Pekeč, S., Vasić, V., Pap,P., Stojnić, S., Kebert, M., Knežević, J., Đorđević, D., (2015): Monitoring and inpact assesment of air polution and its effects in forest ecosistem on the teritory of the Republic of Serbia - Monitoring of forest Condition Level I and level II. Institute of forestry, Belgrade; European Forest Institute; Chapters 2; 3; pp 43 207

***** (2012) Procena i praćenje efekata - uticaja vazdušnih zagađenja na šumske ekosisteme u Republici Srbiji, Institut za šumarstvo, Beograd.

Redfern D B \& Boswell R C (2004) Assessment of crown condition in forest trees: comparison of methods, sources of variation and observer bias. Forest Ecology and Management, 188, 149-160.

Seidling, W., \& Mues, V. (2005). Statistical and geostatistical modelling of preliminarily adjusted defoliation on an European scale. Environmental Monitoring and Assessment, $101,223-247$.

Solberg S \& Strand L (1999) Crown density assessments, control surveys and reproducibility. Environmental Monitoring and Assessment, 56, 75-86.

Tabaković-Tošić M, \& Marković M 2004; The influence of phytophagous insects on the health status of coppice beech forests of eastern Serbia. Collected Works, Collection Tom 50-51. Institute of Forestry, Belgrade, p. 56.

Mihajlović Lj, 2008 Шумарска ентомологија, Уџбеник, Изд. Шумарски факултет, Београд. Forest Entomology, Textbook, Publ. Faculty of Forestry, Belgrade, ISBN 97886-7299-152-9, стр. 499

Karadžić D 2010 Шумска фитопатологија, Уџбеник, Изд. Шумарски факултет, Београд; Шумарски факултет, Бања лука. Forest Phytopathology, Textbook, Publisher: Faculty of Forestry, Belgrade Faculty of Forestry, Banja Luka, ISBN 978-86-7299-177-2, стр. 330

Stefanović T, Nevenić R, Bilibajkić S, Marković N (2003) Istraživanje i ocena praćenja efekata vazdušnih zagađenja na šume u okviru Programa EU - ICP Forests. Zbornik radova, Institut za šumarstvo, Tom 48-49, Beograd, str. 79-87.

Stefanović T., Bilibajkić S., Gagić S. G., Poduška Z., Đorđević I., Češljar G., Nevenić R., (2013): Results of research of defoliation on bio-indicator plots in Republic of Serbia in 2013. Sustainable forestry, Collection tom 67-68: 95-103.

Travaglini D, Fattorini L, Barbati A, Bottalico B, Corona P, Ferretti M, Chirici G (2013) Towards a sampling strategy for the assessment of forest condition at European level: 
combining country estimates Environmental Monitoring and Assessment, Volume 185, Issue 4, pp 3255-3268

UNECE (2004) Manual on methodologies and criteria for modelling and mapping critical loads and levels and air pollution effects, risks and trends. Retrieved from http://www.icpmapping.org 6 May 2014

UNECE (2010) Manual on methods and criteria for harmonized sampling, assessment, monitoring and analysis of the effects of air pollution on forests. Hamburg, Germany: UNECE, ICP Forests Programme Co-ordinating Centre. http://www.icpforests.org/Manual.htm Accessed 27 May 2014.

UNECE (2011) http://www.icp-forests.org/ Accessed 25 May 2014

\section{TABLES AND FIGURES}

Table 1. Classes of defoliation according to UN/ECE and EU classification

\begin{tabular}{lcc}
\hline Class & Degree of defoliation & Needle / leaf loss $\%$ \\
\hline 0 & None & $0-10 \%$ \\
1 & Slight (warning) & $>10-25 \%$ \\
2 & Moderate & $>25-60 \%$ \\
3 & Severe & $>60-100 \%$ \\
4 & Dead & $100 \%$ \\
\hline
\end{tabular}

Table 2. Mean annual value for defoliation of the most common coniferous tree species during period 2012 - 2016. -The average percentage

\begin{tabular}{|c|c|c|c|c|c|}
\hline Year & $\mathbf{2 0 1 2}$ & $\mathbf{2 0 1 3}$ & $\mathbf{2 0 1 4}$ & $\mathbf{2 0 1 5}$ & $\mathbf{2 0 1 6}$ \\
\hline Total coniferous & 10,4 & 11,2 & 12,8 & 12,8 & 13,2 \\
\hline Abies alba & 4,5 & 4,0 & 10,1 & 11,3 & 15,6 \\
\hline Picea abies & 6,1 & 6,0 & 8,0 & 7,7 & 5,9 \\
\hline Pinus nigra & 27,0 & 29,5 & 28,4 & 27,5 & 27,2 \\
\hline Pinus silvestris & 8,9 & 11,6 & 10,0 & 10,1 & 12,4 \\
\hline
\end{tabular}

Table 3. Defoliation in the period 2012 - 2016. Mean annual value for defoliation of the most common broadleaves tree species during period 2012 - 2016 -The average percentage

\begin{tabular}{|l|c|c|c|c|c|}
\hline \multicolumn{1}{|c|}{ Year } & $\mathbf{2 0 1 2}$ & $\mathbf{2 0 1 3}$ & $\mathbf{2 0 1 4}$ & $\mathbf{2 0 1 5}$ & $\mathbf{2 0 1 6}$ \\
\hline Total broadleaves & 12,1 & 15,1 & 13,3 & 11,3 & 12,2 \\
\hline Carpinus betulus & 11,3 & 15,5 & 12,0 & 7,1 & 5,4 \\
\hline Fagus moesiaca & 6,2 & 13,1 & 9,3 & 8,1 & 11,6 \\
\hline Quercus cerris & 15,1 & 16,6 & 14,8 & 12,5 & 12,3 \\
\hline Quercus frainetto & 10,7 & 12,5 & 13,6 & 8,4 & 6,8 \\
\hline Quercus petraea & 17,5 & 18,6 & 16,3 & 13,3 & 14,4 \\
\hline Other species & 18,6 & 17,9 & 17,1 & 17,5 & 18,6 \\
\hline
\end{tabular}

Table 4. Mean annual value for defoliation for both tree species groupes during period 2012 - 2016. - The average percentage

\begin{tabular}{|c|c|c|c|c|c|}
\hline Year & 2012 & 2013 & 2014 & 2015 & 2016 \\
\hline $\begin{array}{c}\text { Total broadleaves } \\
\text { percentage }\end{array}$ & 12,1 & 15,1 & 13,3 & 11,3 & 12,2 \\
\hline $\begin{array}{c}\text { Total coniferous } \\
\text { percentage }\end{array}$ & 10,4 & 11,2 & 12,8 & 12,8 & 13,2 \\
\hline $\begin{array}{c}\text { Total percentage for } \\
\text { both groupes }\end{array}$ & 11,9 & 14,6 & 13,3 & 11,5 & 12,3 \\
\hline
\end{tabular}




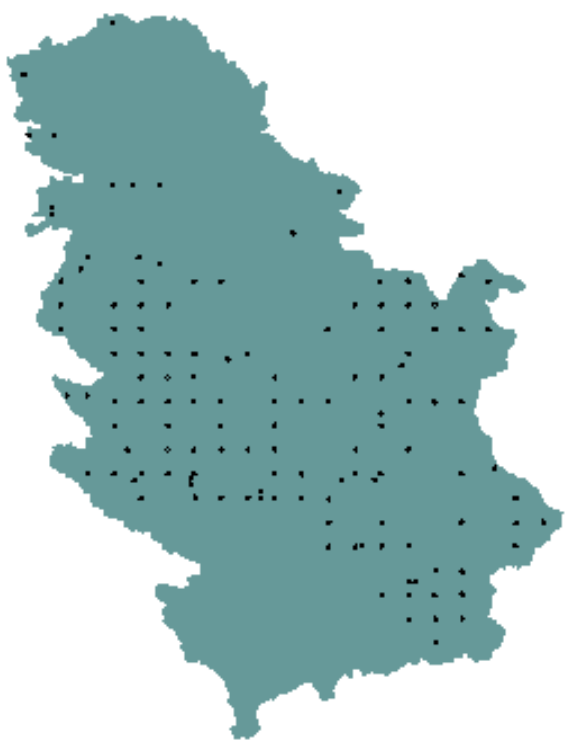

Figure 1. Forest extensive condition monitoring on 130 sample plots (black spots) in Republic of Serbia during period 2009. 2012 (Orig.)

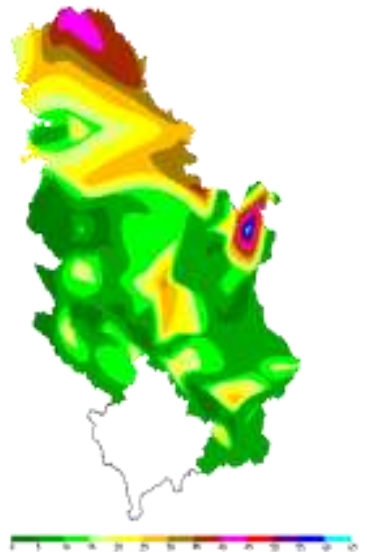

Figure 3. Defoliation in 2012

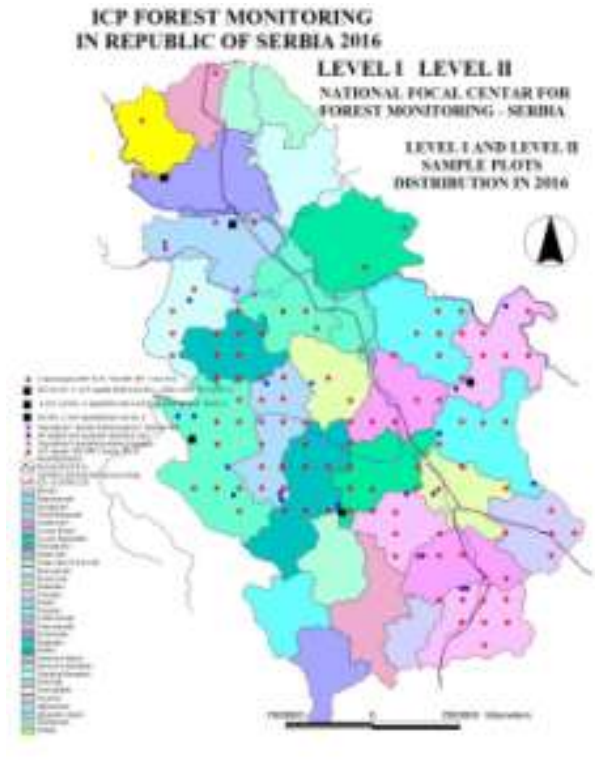

Figure 2. Spatial arrangement of Level I and Level II sample plots on the territory of The Republic of Serbia in 2016 - Geographic Information System application (Orig.)

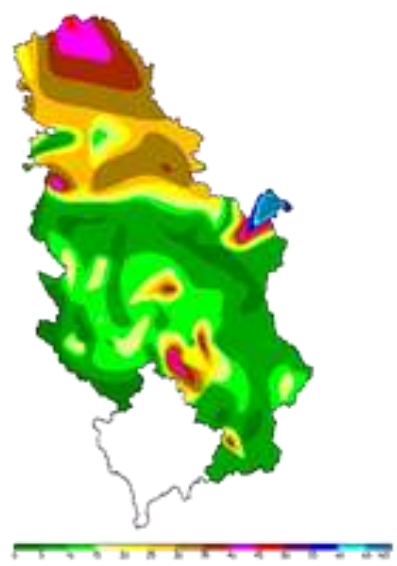

Figure 4. Defoliation in 2013 

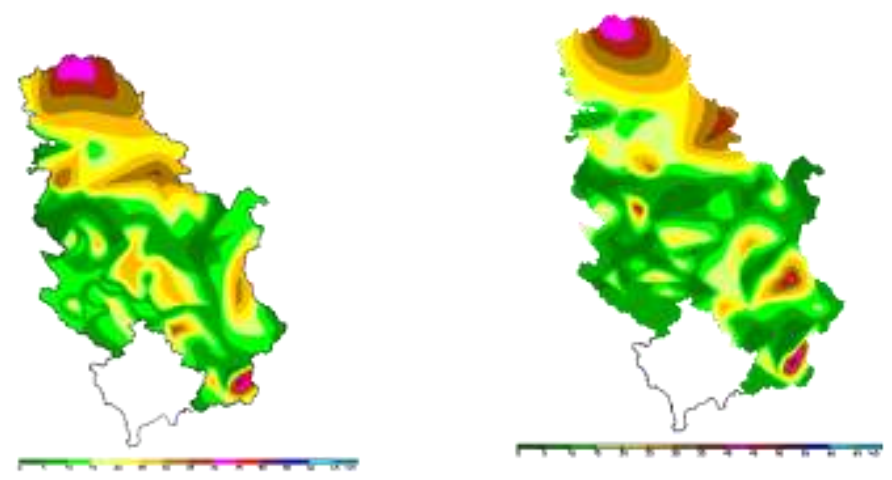

Figure 5. Defoliation in 2014 Figure 6. Defoliation in 2015

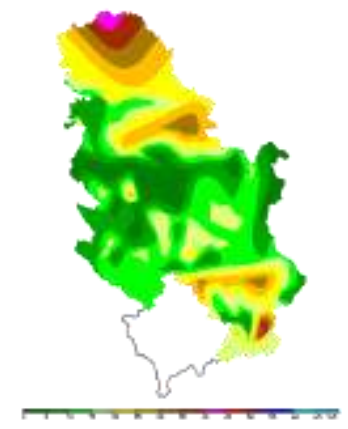

Figure 7. Defoliation in 2016

Legend for Figures 3 - 7. Defoliation maps of forest tree species on the territory of Serbia per year with colured defoliatin range identification

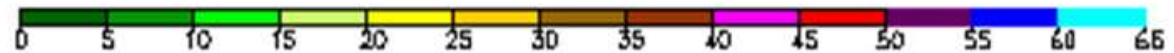




\title{
STUDIES OF DEFOLIATION ON ICP SAMPLE PLOTS LEVEL I IN REPUBLIC OF SERBIA
}

\author{
Tomislav STEFANOVIĆ, Renata GAGIĆ-SERDAR, Ilija ĐORĐEVIĆ, Goran ČEŠLJAR, \\ Natalija MOMIROVIĆ, Ivana ŽIVANOVIĆ, Radovan NEVENIĆ
}

\section{Summary}

Forest Condition Monitoring, Level I, refers primarily to the monitoring and assessment of tree crown defoliation on the installed sample plots, during period of 2012 2016. Forest condition monitoring, with special emphasis on defoliation, were performed on 130 sample plots in the Republic of Serbia. The National Focal Centre for forest monitoring in the Republic of Serbia, within the Institute of Forestry, has been taking an active part in an international program of ICP Forest, by improving its approaches in a goal of monitoring harmonization. Paper presents defoliation as indicator of forest vitality, which occurrence shows certain regularity and can be interpreted as a trend. The degree of defoliation of the crown on broadleaves and coniferous was researched on 130 permanent sample plots in the Republic of Serbia in period 2012 - 2016.. Assessment of defoliation had been assessed on 5\% interval. These plots are systematically arranged in either a 16x16 $\mathrm{km}$ or a $4 \times 4 \mathrm{~km}$ grid system. Defoliation is presented in spatial distribution in Serbia. Results indicate that major defoliation on broadleaves was on Quercus spp., while most resistant was Fagus spp. and Carpinus spp. On coniferous, Pinus spp. has most defoliation and Picea abies was the least affected. Within studieng the impacts of regional climate changes on forest communities, comparative analysis of the data obtained in this period will provide a better insight into the effects of defoliation trends as well as the present health state of forests in Serbia. 